\title{
Phospholipase A as a potent virulence factor of Vibrio vulnificus
}

\author{
BON-SUN KOO ${ }^{1 *}$, JI-HYUN LEE ${ }^{*}$, SOON-CHEOL KIM ${ }^{1}$, HA-YONG YOON ${ }^{1}$, KYUNG-AH KIM $^{1}$, \\ KANG-BEOM KWON ${ }^{2}$, HYUNG-RHO KIM ${ }^{1}$, JIN-WOO PARK ${ }^{1}$ and BYUNG-HYUN PARK ${ }^{1}$ \\ ${ }^{1}$ Department of Biochemistry, Medical School and Institute for Medical Sciences, \\ Chonbuk National University, Jeonju, Jeonbuk 561-756; ${ }^{2}$ Department of Physiology, \\ School of Oriental Medicine, Wonkwang University, Iksan, Jeonbuk 570-749, Korea
}

Received August 9, 2007; Accepted September 24, 2007

\begin{abstract}
Vibrio vulnificus infection has attracted special interest because of its high mortality rate. However, the identification of its major pathogenic determinant still remains obscure. In this study, a cytolysin-negative mutant strain of V. vulnificus CVD707 was used to determine the role of phospholipase A (PLA) in the pathogenesis of this bacterial infection. The mutant strain caused the lysis of erythrocytes in vitro and elevated plasma hemoglobin during the infection in mice. Both the hemolytic and PLA activities were dependent on calcium. Inhibition of hemolysis by PLA inhibitors including tetracyclin and the PLA substrate phosphatidylcholine also supports the possibility of membranous PLA as a major hemolytic factor in the cytolysin-deficient mutant. To identify the role of PLA in the pathogenesis of $V$. vulnificus infection, the effects of tetracycline on bacteriainduced macrophage cytotoxicity and lethality were compared with those of penicillin, an antibiotic with no inhibitory effect on PLA. Both the macrophage cytotoxicity and the lethality of $V$. vulnificus CVD707 to mice were significantly attenuated by tetracycline, but not by penicillin. However, bacterial counts in culture medium and mouse blood revealed that penicillin was more effective than tetracycline in killing bacteria under our experimental conditions. These results indicate that PLA activity is important in V. vulnificus-induced cytotoxicity and lethality, suggesting a crucial role for PLA in the pathogenesis of V. vulnificus infection.
\end{abstract}

Correspondence to: Dr Byung-Hyun Park, Department of Biochemistry, Medical School and Institutes for Medical Sciences, Chonbuk National University, Jeonju, Jeonbuk 561-756, Korea

E-mail: bhpark@chonbuk.ac.kr

${ }^{*}$ Contributed equally

Key words: phospholipase A, hemolysis, tetracycline, calcium, V. vulnificus

\section{Introduction}

Vibrio vulnificus is an estuarine Gram-negative bacterium that causes severe wound infection and fulminant septicemia (1). The infection caused by this bacterium has attracted special attention because of its high patient mortality $(2,3)$. Various factors have been implicated as contributors to the disease caused by $V$. vulnificus. One of these factors is the presence of a cytolysin that causes cell lysis and vascular permeability enhancement (4). This species is also believed to be dependent on the availability of iron in human serum for their survival (5). Other disease factors may include protease (6), phospholipase (7), or the presence of a polysaccharide capsule (8). However, the identity of the major pathogenic determinant still remains obscure.

It is well known that $V$. vulnificus infection is greatly dependent on the blood iron level of the host. Wright et al (5) showed that iron overload in mice greatly reduced the $50 \%$ lethal dose of $V$. vulnificus. Suppressed bacterial growth in iron-deficient medium can be restored by the addition of heme protein or iron-saturated transferrin (9). Epidemiological studies also show that fatal sepsis of $V$. vulnificus is strongly associated with underlying liver diseases such as liver cirrhosis or hemochromatosis, all of which often cause elevated serum iron levels (2,10-12).

$V$. vulnificus is able to utilize various heme-containing compounds, including hemoglobin, as in vitro and in vivo iron sources $(13,14)$. These findings suggest that hemolytic factors produced by the bacterium may play an important role in the pathogenesis of septicemia. $V$. vulnificus cytolysin, originally identified as hemolysin (15), causes the lysis of erythrocytes through the formation of small pores on the cell membrane (16). The capability to produce cytolysin is associated with the virulence of the bacterial strain $(17,18)$. Cytolysin itself is extremely toxic, and even a submicrogram amount of purified cytolysin is fatal to mice when injected intravenously (3). The toxicity of $V$. vulnificus cytolysin is not confined to erythrocytes. It also acts on endothelial and other eukaryotic cells by inducing apoptotic cell death (19). However, the cytolysin-negative mutant strain of $V$. vulnificus still retained its lethal activity on mice (20), suggesting that the role of cytolysin appears to be less important than other factors in the pathogenesis of $V$. vulnificus infection. 
In this study, using the cytolysin-negative mutant strain of $V$. vulnificus, we observed that significantly high hemolytic activity was still retained in vitro, and that plasma hemoglobin was also elevated in infected mice. Seeking the new hemolytic factor in the mutant strain, we found that the major hemolytic and lethal factor was phospholipase A (PLA).

\section{Materials and methods}

Bacterial strain and animals. CVD707, a cytolysin-negative mutant strain of $V$. vulnificus, was kindly donated by J.G. Morris Jr (Division of Infectious Disease, University of Maryland, School of Medicine, Baltimore, MD). Bacteria were cultured in brain heart infusion diffusate broth (Gibco Invitrogen, Carlsbad, CA) at $37^{\circ} \mathrm{C}$ for $4 \mathrm{~h}$ as described by Kreger et al (4). Specific pathogen-free female ICR mice were purchased from the Korean Research Institute of Chemical Technology (Daejon, Korea) and housed in our animal facility for one week before use. All the mice used were 5-6 weeks old. All experimental procedures were approved by the Institutional Animal Care and Use Committee at the Chonbuk National University.

Assay of plasma hemoglobin. V. vulnificus CVD707 ( $\left.1 \times 10^{7} \mathrm{CFU}\right)$ diluted in $100 \mu 1$ of phosphate-buffered saline (PBS) was injected intraperitoneally into mice. At the indicated time, blood samples were collected by heart puncture, immediately transferred to heparinized microfuge tubes, and briefly centrifuged to obtain plasma. Plasma hemoglobin was measured by its myeloperoxidase activity with the method of Anderson et al (21). Plasma (100 $\mu$ l) was added to $1.4 \mathrm{ml}$ of $5 \mathrm{mM}$ potassium phosphate buffer ( $\mathrm{pH}$ 6.0) containing $0.005 \% \mathrm{H}_{2} \mathrm{O}_{2}$ and $0.234 \mathrm{mg} \mathrm{O}$-dianisidine. $\mathrm{A}_{460}$ was measured after a 3-min incubation.

Assay of hemolytic activity. The hemolytic activity of the bacteria or their lysate against mouse erythrocytes was determined by the method of Bernheimer and Schwartz (22). V. vulnificus CVD707 $\left(5 \times 10^{10} \mathrm{CFU} / \mathrm{ml}\right.$ of $50 \mathrm{mM}$ Tris- $\mathrm{HCl}$, $\mathrm{pH}$ 8.0) was lysed by ultrasonification for $2 \mathrm{~min}$ on ice. Intact bacteria or their lysate were mixed with mouse erythrocyte suspensions $\left(0.75 \%\right.$ in $10 \mathrm{mM} \mathrm{CaCl}_{2}, 0.9 \% \mathrm{NaCl}$, and $50 \mathrm{mM}$ Tris- $\mathrm{HCl}, \mathrm{pH} 8.0$ ), and incubated at $37^{\circ} \mathrm{C}$ for $60 \mathrm{~min}$. After brief centrifugation, released hemoglobin in the supernatant was determined by reading the absorbance at $545 \mathrm{~nm}$.

Assay of PLA activity. The PLA activity was determined by the modification of a radioassay developed by Lumb et al (23). One $\mu \mathrm{Ci}$ of ${ }^{14} \mathrm{C}$-phosphatidylcholine (Amersham, Buckinghamshire, UK) and $1.7 \mu \mathrm{mol}$ of unlabelled phosphatidylcholine were dissolved in chloroform and then evaporated. The substrate was re-suspended in $1 \mathrm{ml}$ of $0.1 \%$ deoxycholate, $10 \mathrm{mM} \mathrm{CaCl}_{2}$, and $0.1 \mathrm{M}$ Tris- $\mathrm{HCl}$ buffer, $\mathrm{pH} 8.0$, by vigorous vortexing. Intact bacteria or their lysate and substrate solution $(15 \mu \mathrm{l})$ were added to $0.1 \mathrm{M}$ Tris- $\mathrm{HCl}$ buffer, $\mathrm{pH} 8.0$, containing $0.1 \%$ deoxycholate and $10 \mathrm{mM}$ $\mathrm{CaCl}_{2}$ (total volume, $200 \mu \mathrm{l}$ ), and incubated for $3 \mathrm{~h}$ at $37^{\circ} \mathrm{C}$ in a shaking water bath. After addition of $1 \mathrm{ml}$ of fatty acid extraction mixture (toluene:chloroform:methanol, 1.0:0.5:1.2, v:v:v) and $20 \mu 1$ of $1 \mathrm{~N} \mathrm{NaOH}$, the samples were vigorously

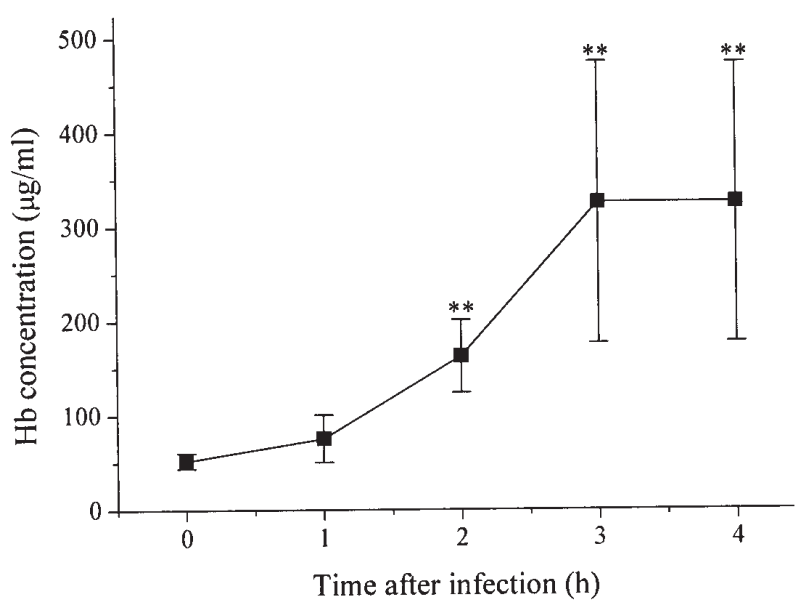

Figure 1. Change of plasma hemoglobin in mice infected with cytolysindeficient $V$. vulnificus. Mice were infected with an intraperitoneal injection of $V$. vulnificus CVD707 (10 7 CFU). Blood was taken at the indicated times, and the plasma hemoglobin $(\mathrm{Hb})$ level was determined by the myeloperoxidase method. Each point is the mean \pm SE obtained from 4 animals. ${ }^{* *} \mathrm{P}<0.01$ vs. time 0 .

vortexed and centrifuged at $1,000 \mathrm{x}$ g for $10 \mathrm{~min}$ to separate the aqueous and organic phases. The radioactivity in aqueous phase $(400 \mu 1)$ was determined by a scintillation counter.

Preparation of peritoneal macrophage and cytotoxicity assay. Murine macrophages were obtained from ICR mice that had been injected with $2 \mathrm{ml}$ of sterile $3 \%$ thioglycolate (24). Four days after injection, peritoneal exudate cells were harvested by peritoneal lavage with $6 \mathrm{ml}$ of ice-cold PBS per mouse. These cells were washed twice and then suspended at $5 \times 10^{6}$ cells $/ \mathrm{ml}$ in DMEM supplemented with $10 \%$ fetal bovine serum, $100 \mathrm{IU} / \mathrm{ml}$ penicillin $\mathrm{G}$, and $5 \mu \mathrm{g} / \mathrm{ml}$ streptomycin (working medium). After a 2-h incubation in $75-\mathrm{cm}^{2}$ culture flasks at $37^{\circ} \mathrm{C}$ in a humidified $95 \%$ air $/ 5 \% \mathrm{CO}_{2}$ atmosphere, nonadherent cells were removed by repeated washing with ice-cold PBS. Adherent cells (peritoneal exudate macrophage) were harvested using a cell scraper and re-suspended at $10^{6}$ cells $/ \mathrm{ml}$ in working medium. The macrophages obtained $\left(10^{6}\right.$ cells) in this step were incubated with $V$. vulnificus CVD707 in $300 \mu \mathrm{l} \mathrm{DMEM}$ at $37^{\circ} \mathrm{C}$ for $3 \mathrm{~h}$, and cell viability was determined by the ability to exclude trypan blue (25).

Statistical analysis. Statistical analysis of the data was performed with the Student's t-test and ANOVA followed by the Duncan's test. Differences of $\mathrm{P}<0.05$ were considered statistically significant.

\section{Results}

The bacterial strain used in these experiments was CVD707, a cytolysin-negative mutant strain of $V$. vulnificus (20). To determine whether hemolysis was still induced in mice infected with a cytolysin-deficient strain, plasma hemoglobin levels were measured after bacterial injection. As shown in Fig. 1, plasma hemoglobin levels were significantly increased in a time-dependent manner after bacterial injection. This finding suggests that iron overload through hemolysis still 
Table I. Existence of PLA and hemolytic activities of cytolysin-deficient $V$. vulnificus.

\begin{tabular}{lcc}
\hline Fractions & $\begin{array}{c}\text { PLA } \\
\text { activity (\%) }\end{array}$ & $\begin{array}{c}\text { Hemolytic } \\
\text { activity (\%) }\end{array}$ \\
\hline Intact V. vulnificus CVD707 & 100 & 100 \\
V. vulnificus CVD707 lysate & $104.5 \pm 7.6$ & $100.9 \pm 13.4$ \\
$\begin{array}{l}\text { Heat-treated } \text { V. vulnificus } \\
\text { CVD707 lysate }\end{array}$ & $3.3 \pm 0.6^{\mathrm{a}}$ & ND
\end{tabular}

The results are expressed as the mean \pm SE of 4 separate experiments. $\mathrm{ND}$, not detectable. ${ }^{\mathrm{a}} \mathrm{P}<0.01$ vs. intact $V$. vulnificus CVD707.

Table II. Agents inhibiting PLA and hemolytic activities of cytolysin-deficient $V$. vulnificus.

\begin{tabular}{lcc}
\hline Inhibitors & $\begin{array}{c}\text { PLA } \\
\text { activity (\%) }\end{array}$ & $\begin{array}{c}\text { Hemolytic } \\
\text { activity (\%) }\end{array}$ \\
\hline None & 100 & 100 \\
Phosphatidylcholine, $100 \mu \mathrm{g} / \mathrm{ml}$ & $6.0 \pm 3.9^{\mathrm{b}}$ & $10.5 \pm 0.7^{\mathrm{b}}$ \\
Streptomycin, $1 \mathrm{mM}$ & $30.1 \pm 4.1^{\mathrm{a}}$ & $14.3 \pm 5.1^{\mathrm{b}}$ \\
Quinacrine, $1 \mathrm{mM}$ & $26.3 \pm 3.7^{\mathrm{a}}$ & $17.3 \pm 5.1^{\mathrm{b}}$ \\
4-Bromophenacyl bromide, $1 \mathrm{mM}$ & $67.2 \pm 11.0$ & $\mathrm{ND}$ \\
Quercetin, $1 \mathrm{mM}$ & $90.0 \pm 21.8$ & $79.6 \pm 14.3$ \\
Tetracyclin, $10 \mu \mathrm{M}$ & $40.1 \pm 6.7^{\mathrm{a}}$ & $21.4 \pm 9.2^{\mathrm{a}}$ \\
Penicillin, $1 \mathrm{mM}$ & $96.4 \pm 7.1$ & $93.9 \pm 2.0$ \\
\hline
\end{tabular}

The results are expressed as the mean $\pm \mathrm{SE}$ of 4 separate experiments. $\mathrm{ND}$, not determined because of the reagent's own hemolytic activity. ${ }^{\mathrm{a}} \mathrm{P}<0.05,{ }^{\mathrm{b}} \mathrm{P}<0.01$ vs. none.

occurs in the absence of cytolysin, and other hemolytic factors may participate in hemolysis caused by mutant bacteria.

Intact bacteria and lysate of the cytolysin-deficient strain were both equally able to cause the lysis of erythrocytes in vitro (Table I). The bacterial lysate was extremely heatlabile, showing complete loss of hemolytic and PLA activities even at $50^{\circ} \mathrm{C}$ for $10 \mathrm{~min}$.

The effects of various PLA inhibitors on the hemolytic and PLA enzyme activities of $V$. vulnificus CVD707 lysate are presented in Table II. The presence of excess phosphatidylcholine, a substrate of phospholipase, competitively inhibited the hemolytic activity of intact bacteria, suggesting that phospholipase was a possible hemolytic factor. Inhibition of PLA activities with tetracycline (26), quinacrine (27), quercetin (28), 4-bromophenacyl bromide (28), or streptomycin (29) was observed with varying degrees, and these changes in PLA activity were well correlated with changes in hemolytic activity.

Among the inhibitors used, tetracycline was most potent (Table II). Dose-dependent inhibition of phospholipase A

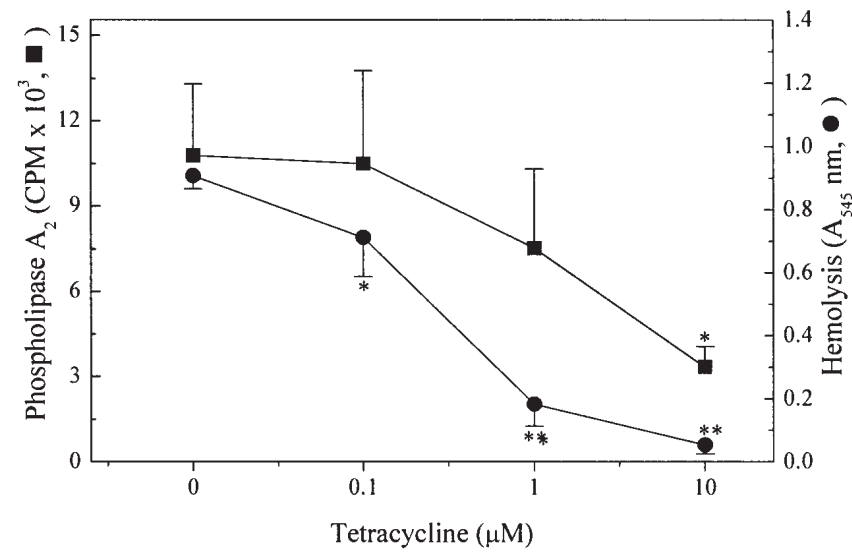

Figure 2. Inhibitory effect of tetracycline on PLA and hemolytic activities of cytolysin-deficient $V$. vulnificus. PLA and hemolytic activities of V. vulnificus CVD707 lysate were determined at various concentrations of tetracycline as described in Materials and methods. The results are expressed as the mean $\pm \mathrm{SE}$ of 3 separate experiments. ${ }^{*} \mathrm{P}<0.05,{ }^{* *} \mathrm{P}<0.01$ vs. none.

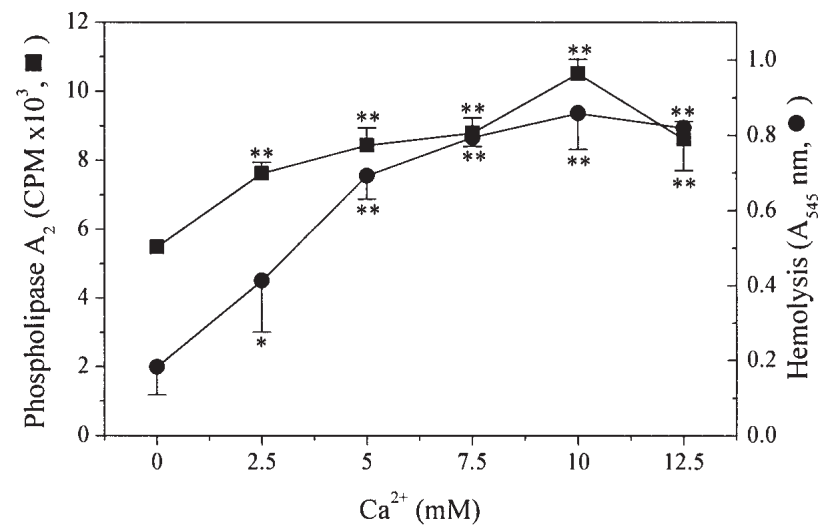

Figure 3. Effect of calcium on PLA and hemolytic activities of cytolysindeficient $V$. vulnificus. PLA and hemolytic activities of $V$. vulnificus CVD707 lysate were determined at various concentrations of $\mathrm{Ca}^{2+}$ as described in Materials and methods. The results are expressed as the mean \pm $\mathrm{SE}$ of 3 separate experiments. ${ }^{*} \mathrm{P}<0.05,{ }^{* *} \mathrm{P}<0.01$ vs. none.

activity with tetracycline was accompanied by the inhibition of hemolysis in a concentration-dependent manner (Fig. 2). Most PLA enzymes require calcium for their activation (15). As shown in Fig. 3, both the hemolytic and PLA activities of bacterial lysate were greatly enhanced by calcium in the reaction mixture. These results again strongly support the possibility of PLA as a major hemolytic factor in this cytolysin-deficient $V$. vulnificus mutant strain.

Our next step was to define the role of PLA as a virulence determinant in $V$. vulnificus CVD707 infection. Therefore, we investigated the effects of PLA inhibitors on $V$. vulnificus CVD707-induced cytotoxicity of macrophages and bacterial viability. However, the effective concentrations for most of these PLA inhibitors were much higher than that of tetracycline; high enough to cause severe toxicity in cell and animal studies (Table II). As tetracycline is an antibiotic compound, another antibiotic, penicillin, was chosen for comparison studies. Penicillin exhibited no inhibition of PLA 
(A)

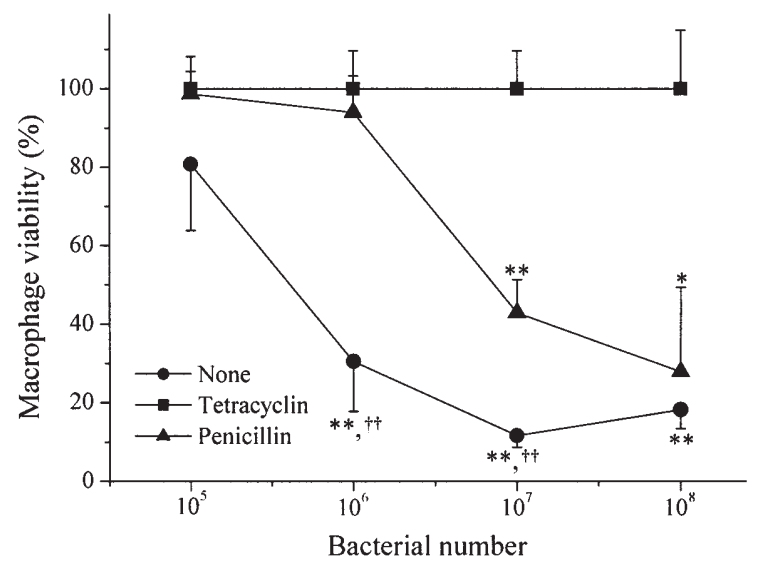

(B)

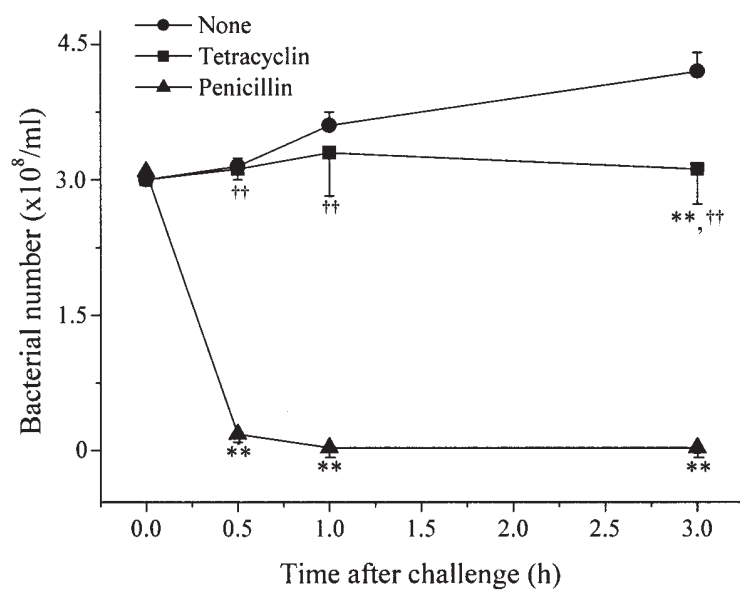

Figure 4. Effects of tetracycline and penicillin on cytolysin-deficient V. vulnificus-induced macrophage damage (A) and bacterial viability (B). Murine macrophages $\left(10^{6}\right.$ cells) were incubated with an indicated amount of V. vulnificus CVD707 at $37^{\circ} \mathrm{C}$ for $3 \mathrm{~h}$ in the presence or absence of $10 \mu \mathrm{M}$ tetracycline or $50 \mu \mathrm{M}$ penicillin in $300 \mu \mathrm{l}$ DMEM, and cell viability was determined by the ability to exclude trypan blue (A). To check bacterial susceptibility to antibiotics, V. vulnificus CVD707 (107 CFU) were incubated at $37^{\circ} \mathrm{C}$ for the indicated time in the presence or absence of $10 \mu \mathrm{M}$ tetracycline or $50 \mu \mathrm{M}$ penicillin in $300 \mu 1 \mathrm{DMEM}$, and the number of colonies was counted after culturing at $\mathrm{BHI}$ agar at $37^{\circ} \mathrm{C}$ overnight (B). Each value denotes the mean $\pm \mathrm{SE}$ of 3 experiments. ${ }^{*} \mathrm{P}<0.05,{ }^{* *} \mathrm{P}<0.01$ vs. none; ${ }^{\dagger} \mathrm{P}<0.01$ vs. the penicillin-treated group.

and hemolytic activities even at a 1-mM concentration. But tetracycline, at a concentration $1 / 100$ th that of penicillin, significantly inhibited PLA and hemolytic activities (Table II).

When murine macrophages $\left(10^{6}\right.$ cells $)$ were incubated with $V$. vulnificus CVD707 (10 $7 \mathrm{CFU})$ in culture medium, $\sim 90 \%$ of cells were dead within $3 \mathrm{~h}$ (Fig. 4A) and the number of bacteria was gradually increased during the culture (Fig. 4B). In the presence of $50 \mu \mathrm{M}$ penicillin, this cytotoxicity to macrophages was somewhat attenuated, but still persisted; $42.8 \pm 8.6 \%$ of the macrophages were still alive at bacterial concentrations of $10^{7} \mathrm{CFU}$ in the culture medium (Fig. 4A). However, most of the bacteria were dead at $30 \mathrm{~min}$ after culture with penicillin (Fig. 4B). In contrast, cytotoxicity against macrophages was completely prevented by $10 \mu \mathrm{M}$ tetracycline at bacterial counts ranging from $10^{5}$ to $10^{8} \mathrm{CFU}$ (Fig. 4A). The number of viable bacteria in the medium remained static until $3 \mathrm{~h}$ (Fig. 4B).
(A)
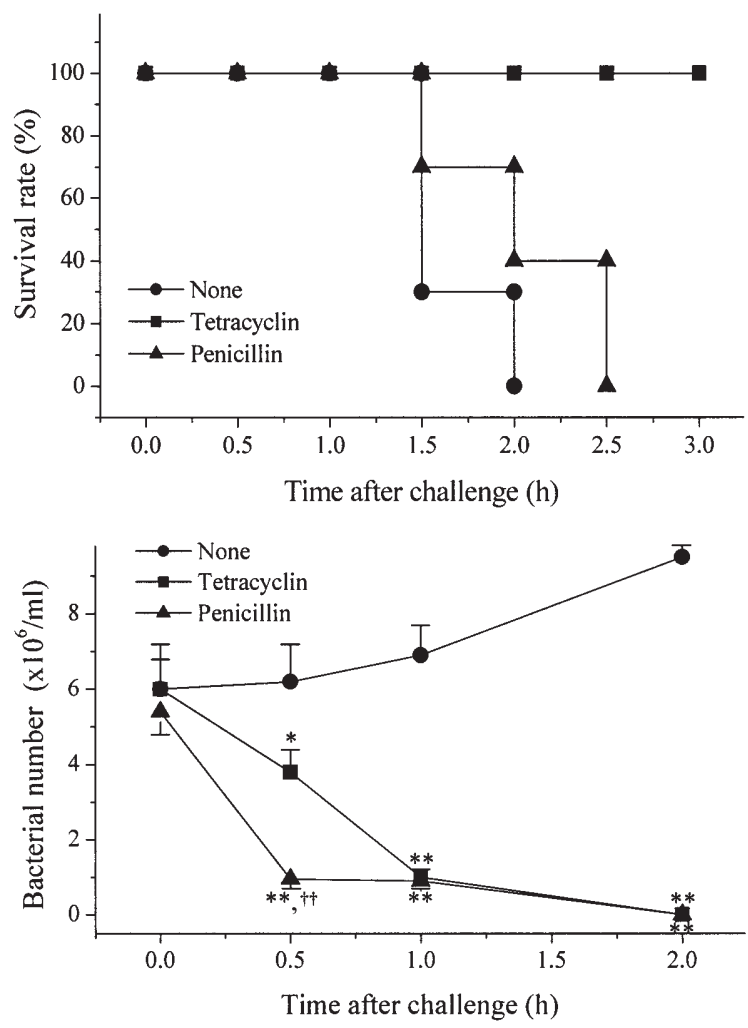

Figure 5. Effect of tetracycline and penicillin on lethality by cytolysindeficient $V$. vulnificus (A) and blood bacterial number (B) in mice. Mice (10 for each group) were treated with vehicle, tetracycline $(5 \mathrm{mg} / \mathrm{kg}$ i.v. $)$ or penicillin $(25 \mathrm{mg} / \mathrm{kg}$ i.v.) just before the intraperitoneal injection of $V$. vulnificus CVD707 (10 ${ }^{8} \mathrm{CFU}$ ), and their survival was monitored for $3 \mathrm{~h}(\mathrm{~A})$. For blood bacterial counting, blood was taken at the indicated time and cultured at BHI agar at $37^{\circ} \mathrm{C}$ overnight, and the number of colonies was counted (B). Each value denotes the mean \pm SE of 4 mice. ${ }^{*} \mathrm{P}<0.05$, ${ }^{* *} \mathrm{P}<0.01$ vs. none; ${ }^{\dagger} \mathrm{P}<0.01$ vs. the penicillin-treated group.

Similar results were observed for the mortality of mice infected with $V$. vulnificus CVD707. At a dosage of $10^{8} \mathrm{CFU}$, all mice were dead in $2 \mathrm{~h}$ (Fig. 5A), and the number of viable bacteria in the blood was greatly increased (Fig. 5B). A prior injection of penicillin killed most of the bacteria in the blood within $30 \mathrm{~min}$ (Fig. 5B), but could not prevent death caused by bacterial infection (Fig. 5A). The bactericidal efficiency of tetracycline was weaker than that of penicillin (Fig. 5B), however, all the mice were alive under the same conditions of infection (Fig. 5A). These results suggest that PLA activity is an important determinant in $V$. vulnificus CVD707-induced cytotoxicity and lethality.

\section{Discussion}

Iron increases the growth rate of $V$. vulnificus in cultures as well as in mice $(13,30)$, and hemoglobin released through hemolysis is an important source of plasma iron $(13,14)$. The role of iron in the animal host is thought to greatly facilitate the proliferation of $V$. vulnificus, increasing the bacterial number beyond the capability of the mouse defense system to effectively reduce it. The resultant high numbers of bacteria cause death (30). The final mechanism of lethality therefore appears to be independent of iron. Such toxicity could be 
caused by the increase in some toxic factors produced by large numbers of bacteria. $V$. vulnificus cytolysin was thought to be a potent virulence determinant in bacterial infection (3) and was originally identified as a hemolysin causing the lysis of cells (31). In this study, we used CVD707, a cytolysinnegative mutant strain of $V$. vulnificus. Wright and Morris (20) used the same strain, and reported that it was still lethal to mice. In spite of the mutation to the cytolysin gene, elevation of plasma hemoglobin was still observed during infection with the mutant strain. Furthermore, the mutant bacteria itself can cause lysis of erythrocytes in vitro. These results indicate that a new hemolytic factor is present in the cytolysin-negative mutant strain, and it provides enough cellfree blood iron for bacterial growth.

To aid in the invasion of host tissues, microbial cells possess constitutive and inducible hydrolytic enzymes that destroy or derange constituents of host cell membranes, leading to membrane dysfunction and/or physical disruption. By cleaving phospholipids, phospholipases destabilize the membrane resulting in cell lysis. Evidence implicating phospholipase in host cell penetration, injury, and lysis by microorganisms has been reported in various types of bacteria and fungi $(32,33)$. Consequently, phospholipases have been included among the virulence factors that damage host cells.

The bacterial phospholipases comprise a diverse group of proteins that are considered to be virulence factors for bacterial species that cause serious diseases. Such illnesses range from infections causing massive tissue destruction, such as gas gangrene and lung infections of Pseudomonas aeruginosa, to food-borne listeriosis (32-34). Triggering bacterial entry, endosomal lysis, and cytolysis to modulate the local immune response and stimulating cytokine secretion (34) were also suspected to be action mechanisms of phospholipases in diseases. The requirement of calcium as a cofactor for enzymatic activity of outer membranous forms of PLA (OMPLA) has been reported in Gram-negative bacteria. Its activity is calcium-dependent and strictly regulated by reversible dimerization $(9,15,35,36)$. Our enzyme was also calcium-dependent. PLA activity was determined using a radioactive fatty acid attached at the $s n-2$ position of glycerol. The identity of our PLA and its relationship with the already reported OMPLA and the specificity of $V$. vulnificus phospholipase are both topics that need further study. Strong inhibition of hemolysis by PLA inhibitors including tetracycline and phosphatidylcholine was observed in this study. Such data also support the possibility that membranous PLA of V. vulnificus is a major hemolytic factor in a cytolysindeficient mutant strain. Testa et al (7) have already reported the presence of phospholipase activity in $V$. vulnificus. However, it was a secretory enzyme and could not cause the lysis of erythrocytes.

To identify the role of PLA in the virulence of $V$. vulnificus infection, bacteria-induced cytotoxicity and lethality were studied in the presence of the PLA inhibitor tetracycline. The effect of tetracycline was compared to that of penicillin, another antibiotic with no inhibitory effect on PLA. Both the V. vulnificus CVD707-induced cytotoxicity of macrophage and lethality to mice were significantly prevented by tetracycline, but not by penicillin, suggesting that PLA might play an important role in the pathogenesis of $V$. vulnificus infection. Counts of bacterial numbers in the medium and blood revealed that penicillin had a more potent bactericidal effect than tetracycline. However, their effects on cytotoxicity and lethality were the opposite; tetracycline was much more effective in the prevention of cytotoxicity and lethality. These results suggest that even when alive, $V$. vulnificus is not cytotoxic and lethal when its membranous PLA is inactive. A supply of sufficient iron through PLA-induced hemolysis may facilitate $V$. vulnificus growth and pathogenesis. Inhibition of PLA by tetracycline may be one of the reasons why tetracycline has been used successfully as a drug of choice in $V$. vulnificus infection.

Taken together, our study suggests that $V$. vulnificus PLA plays a pivotal role as a major pathogenic determinant in $V$. vulnificus infection. Compared with phospholipase $\mathrm{C}$ or phospholipase D $(32,33)$, little is known about the lethal mechanism of bacterial PLA. Only their potential roles in terms of the disruption of host membranes as well as providing precursors to eicosanoid synthesis are known (34). Better knowledge about the exact mechanism of $V$. vulnificus PLA and its cytosolic cofactor in cytotoxicity and lethality will be helpful in treating $V$. vulnificus infection.

\section{Acknowledgements}

This work was supported by a grant from Kye-Nam, Kim Jae-Jung Memorial Fund (to B-H.P.) and by the Regional Research Centers Program of the Korean Ministry of Education and Human Resources Development through the Center for Healthcare Technology Development.

\section{References}

1. Blake PA, Merson MH, Weaver RE, Hollis DG and Heublein PC: Disease caused by a marine Vibrio. Clinical characteristics and epidemiology. N Engl J Med 300: 1-5, 1979.

2. Hlady WG and Klontz KC: The epidemiology of Vibrio infections in Florida, 1981-1993. J Infect Dis 173: 1176-1183, 1996.

3. Park JW, Ma SN, Song ES, Song CH, Chae MR, Park BH, Rho RW, Park SD and Kim HR: Pulmonary damage by Vibrio vulnificus cytolysin. Infect Immun 64: 2873-2876, 1996.

4. Kreger AS, Kothary MH and Gray LD: Cytolytic toxins of Vibrio vulnificus and Vibrio damsela. Methods Enzymol 165: 176-189, 1988.

5. Wright AC, Simpson LM and Oliver JD: Role of iron in the pathogenesis of Vibrio vulnificus infections. Infect Immun 34: 503-507, 1981.

6. Miyoshi S and Shinoda S: Role of the protease in the permeability enhancement by Vibrio vulnificus. Microbiol Immunol 32: 1025-1032, 1988.

7. Testa J, Daniel LW and Kreger AS: Extracellular phospholipase A2 and lysophospholipase produced by Vibrio vulnificus. Infect Immun 45: 458-463, 1984

8. Wright AC, Powell JL, Kaper JB and Morris JG Jr: Identification of a group 1-like capsular polysaccharide operon for Vibrio vulnificus. Infect Immun 69: 6893-6901, 2001.

9. Nishijima M, Nakaike S, Tamori Y and Nojima S: Detergentresistant phospholipase A of Escherichia coli K-12. Purification and properties. Eur J Biochem 73: 115-124, 1977.

10. Park SD, Shon HS and Joh NJ: Vibrio vulnificus septicemia in Korea: clinical and epidemiologic findings in seventy patients. J Am Acad Dermatol 24: 397-403, 1991.

11. Hor LI, Chang TT and Wang ST: Survival of Vibrio vulnificus in whole blood from patients with chronic liver diseases: association with phagocytosis by neutrophils and serum ferritin levels. J Infect Dis 179: 275-278, 1999.

12. Bullen JJ, Spalding PB, Ward CG and Gutteridge JM: Hemochromatosis, iron and septicemia caused by Vibrio vulnificus. Arch Intern Med 151: 1606-1609, 1991. 
13. Helms SD, Oliver JD and Travis JC: Role of heme compounds and haptoglobin in Vibrio vulnificus pathogenicity. Infect Immun 45: 345-349, 1984.

14. Nishina Y, Miyoshi S, Nagase A and Shinoda S: Significant role of an exocellular protease in utilization of heme by Vibrio vulnificus. Infect Immun 60: 2128-2132, 1992.

15. Snijder HJ and Dijkstra BW: Bacterial phospholipase A: structure and function of an integral membrane phospholipase. Biochim Biophys Acta 1488: 91-101, 2000.

16. Kim HR, Rho HW, Jeong MH, Park JW, Kim JS, Park BH, Kim UH and Park SD: Hemolytic mechanism of cytolysin produced from $V$. vulnificus. Life Sci 53: 571-577, 1993.

17. Oliver JD, Wear JE, Thomas MB, Warner M and Linder K: Production of extracellular enzymes and cytotoxicity by Vibrio vulnificus. Diagn Microbiol Infect Dis 5: 99-111, 1986.

18. Stelma GN Jr, Reyes AL, Peeler JT, Johnson CH and Spaulding PL: Virulence characteristics of clinical and environmental isolates of Vibrio vulnificus. Appl Environ Microbiol 58: 2776-2782, 1992.

19. Kwon KB, Yang JY, Ryu DG, Rho HW, Kim JS, Park JW, Kim HR and Park BH: Vibrio vulnificus cytolysin induces superoxide anion-initiated apoptotic signaling pathway in human ECV304 cells. J Biol Chem 276: 47518-47523, 2001.

20. Wright AC and Morris JG Jr: The extracellular cytolysin of Vibrio vulnificus: inactivation and relationship to virulence in mice. Infect Immun 59: 192-197, 1991.

21. Anderson BO, Brown JM, Shanley PF, Bensard DD and Harken AH: Marginating neutrophils are reversibly adherent to normal lung endothelium. Surgery 109: 51-61, 1991.

22. Bernheimer AW and Schwartz LL: Isolation and composition of staphylococcal alpha-toxin. J Gen Microbiol 30: 455-468, 1963.

23. Lumb MR, Roseblade CK, Helmig R, Uldbjerg N, Sullivan MH and Elder MG: Use of a new simplified assay for phospholipase $\mathrm{A}_{2}$ to measure bacterial enzyme levels. Clin Chim Acta 189: 39-46, 1990.

24. Mishell BB and Shiigi SM. Preparation of mouse cell suspensions. In: Selected Methods in Cellular Immunology. Mishell BB and Shiigi SM (eds). W.H. Freeman and Company, San Francisco, pp3-27, 1980.
25. Detrick-Hooks B, Borsos T and Rapp HJ: Quantitative comparison of techniques used to measure complement-mediated cytotoxicity of nucleated cells. J Immunol 114: 287-290, 1975.

26. Pruzanski W, Stefanski E, Vadas P, McNamara TF, Ramamurthy $\mathrm{N}$ and Golub LM: Chemically modified nonantimicrobial tetracyclines inhibit activity of phospholipases $\mathrm{A}_{2}$. J Rheumatol 25: 1807-1812, 1998.

27. Chan AC, Pritchard ET, Gerrard JM, Man RY and Choy PC: Biphasic modulation of platelet phospholipase $\mathrm{A}_{2}$ activity and platelet aggregation by mepacrine (quinacrine). Biochim Biophys Acta 713: 170-172, 1982.

28. Lanni $C$ and Becker EL: Inhibition of neutrophil phospholipase A2 by p-bromophenylacyl bromide, nordihydroguaiaretic acid, 5,8,11,14-eicosatetraynoic acid and quercetin. Int Arch Allergy Appl Immunol 76: 214-217, 1985.

29. Hostetler KY and Hall LB: Inhibition of kidney lysosomal phospholipases $\mathrm{A}$ and $\mathrm{C}$ by aminoglycoside antibiotics: possible mechanism of aminoglycoside toxicity. Proc Natl Acad Sci USA 79: 1663-1667, 1982.

30. Hor LI, Chang YK, Chang CC, Lei HY and Ou JT: Mechanism of high susceptibility of iron-overloaded mouse to Vibrio vulnificus infection. Microbiol Immunol 44: 871-878, 2000.

31. Shinoda S, Miyoshi S, Yamanaka H and Miyoshi-Nakahara N: Some properties of Vibrio vulnificus hemolysin. Microbiol Immunol 29: 583-590, 1985.

32. Ghannoum MA: Potential role of phospholipases in virulence and fungal pathogenesis. Clin Microbiol Rev 13: 122-143, 2000.

33. Songer JG: Bacterial phospholipases and their role in virulence. Trends Microbiol 5: 156-161, 1997.

34. Schmiel DH and Miller VL: Bacterial phospholipases and pathogenesis. Microbes Infect 1: 1103-1112, 1999.

35. Dekker N: Outer-membrane phospholipase A: known structure, unknown biological function. Mol Microbiol 35: 711-717, 2000.

36. Ubarretxena-Belandia I, Boots JW, Verheij HM and Dekker N: Role of the cofactor calcium in the activation of outer membrane phospholipase A. Biochemistry 37: 16011-16018, 1998. 